\title{
Études/Inuit/Studies
}

\section{UNESCO, 2009 Climate Change and Arctic Sustainable Development: Scientific, Social, Cultural and Educational Challenges, Paris, UNESCO Publishing, 357 pages.}

\section{A. Nicole Stuckenberger}

Volume 34, numéro 1, 2010

Les Inuit et le changement climatique

The Inuit and Climate Change

URI : https://id.erudit.org/iderudit/045415ar

DOI : https://doi.org/10.7202/045415ar

Aller au sommaire du numéro

\section{Éditeur(s)}

Association Inuksiutiit Katimajiit Inc.

Centre interuniversitaire d'études et de recherches autochtones (CIÉRA)

ISSN

0701-1008 (imprimé)

1708-5268 (numérique)

Découvrir la revue

Citer ce compte rendu

Stuckenberger, A. N. (2010). Compte rendu de [UNESCO, 2009 Climate Change and Arctic Sustainable Development: Scientific, Social, Cultural and Educational Challenges, Paris, UNESCO Publishing, 357 pages.] Études/Inuit/Studies, 34(1), 180-182. https://doi.org/10.7202/045415ar d'utilisation que vous pouvez consulter en ligne. 


\section{A. Nicole Stuckenberger Institute of Arctic Studies John Sloan Dickey Center for International Understanding Dartmouth College, Hanover, NH 03755, USA astuckenberger@lstc.edu}

\section{UNESCO}

2009 Climate Change and Arctic Sustainable Development: Scientific, Social, Cultural and Educational Challenges, Paris, UNESCO Publishing, 357 pages.

Climate Change and Arctic Sustainable Development is not a contribution that advances our understanding of the integration of local and scientific knowledge or the relationship between scientific knowledge, economy, and political power. In a way, it very much reflects the situation that has already been described in similar documents. It is a proposal to move ahead, a good overview of Arctic climate change.

Global climate change is heavily impacting the Arctic environment and is affecting Arctic economic development, international relations, and day-to-day living conditions in northern communities. Because of these far-reaching and diverse implications, climate change is experienced and dealt with in a variety of partly competing realities. The current situation calls for decided and concerted action, but who is going to shape the future, and how? On the basis of what kind of knowledge and values should we act? What do we have to learn? These questions have led to several recent publications, such as Intergovernmental Panel on Climate Change Report, the Arctic Climate Impact Assessment, and the Arctic Human Development Report, and now they are addressed in a similar fashion by the UNESCO publication Climate Change and Arctic Sustainable Development: Scientific, Social, Cultural and Educational Challenges (2009). It aims to help develop effective and socially just ways of understanding and dealing with the challenges of climate change, mainly through the establishment of extensive structures and programs that interconnect scientists and also local communities and policymakers.

The publication evolved from the international meeting, "Climate Change and Arctic Sustainable Development” held in 2009 in Monaco, which representatives of the scientific community, civil society, governments, and national and international organisations attended as contributors and panellists. The resulting 35 papers are organised into eight sections: oceans and atmosphere; biodiversity and ecosystem services; community-level impacts and adaptation; health and well-being; economic development and social transformations; education; ethics, responsibility and sustainability; and monitoring systems. Each paper both introduces the findings of a specific field or perspective and, to various degrees, discusses them in light of the interdisciplinary themes of education and sustainable development, monitoring and observing systems, environmental ethics, and global connections to change in the Arctic. The papers are mostly based on materials already published elsewhere, but also

\section{0/RECENSIONS}


include new insights gleaned from the International Polar Year (IPY), local monitoring and educational projects, recent scientific data, and perspectives from political initiatives, such as Indigenous progress toward self-government.

The annex contains an excellent overview of the results and proposed projects and developments, while subjecting them to critical reflections. It is perhaps in this annex that the intended integrative perspective on climate change is best brought to bear. The summary effectively highlights the interrelatedness of Arctic realities and thus argues strongly for establishing and funding future projects as well as large-scale collaborative programs and structures. If you are new to the issue of Arctic climate change or want to broaden your perspective, I recommend browsing through all of the papers and selectively reading at least those that are of particular interest to you, in combination with a careful study of the annex.

Most of the authors share a wish to improve communication, be it in the form of scientific (interdisciplinary) data-generating and data-sharing networks, effective dissemination of findings to the wider public, or advancements in understanding and levelling the playing fields between various Arctic and international stakeholders, especially with regard to research, economic development, and decision-making. Although power relationships arguably shape the dynamics and contents of communication, they at best remain implicit in most of the papers, except for the ones by Indigenous leaders and social scientists. Most of the papers actually stress the unequal allocation of voices in climate-change discourses. Other papers reflect on the epistemological opportunities and difficulties of integrating various kinds of knowledge, without suggesting concrete ways of dealing with diversity within a framework of fair and equitable conduct in and between societies and communities.

Power is a complex issue. It cuts across politics, cultural and historic assumptions, economic interests, and, especially in the context of climate-change discourses, understanding of what kind of knowledge provides a valid and relevant basis for decision-making. Also, why do major programs, such as IPY and this UNESCO project, continue to exclude leading (and science-friendly) churches, or other religious representatives, from the conference table? In Canada and Alaska, for example, Christianity is an integral part of community life and, in my experience, often included in decision-making. A religious perspective, whether Christian or other, would complement the ethical dimension of climate-change discourse with a spiritual voice relevant to both Arctic and Western societies. Therefore, a more than incidental partnership requires nothing less than a review of how we deal with the boundaries of our diverse cultures (including those of the scientific, financial, and policy-making communities). With regard to Western lifeways, we may have to re-think relationships between, for example, the natural and social sciences, between objective and holistic knowledge, between science and religion, and between the experiences of the privileged and underprivileged. How do we want to deal with difference?

Several papers and the annex of Climate Change and Arctic Sustainable Development approach the power issue from the perspective of education. They aim to counter the increasingly stereotypical and courteous discourse that currently brings 
together science, Indigenous people, economic development, and policy-making. Their argument is that more productive communication can be fostered through deeper understanding of the kinds of knowledge related to climate-change discourse. Especially interesting in this respect is Lene Kielsen Holm et al.'s (pp. 45-52) paper on the experiential approach of the Siku-Inuit-Hila project. Sending Inuit and scientists together on a journey out on the ice-the element central to each participant's lifeprovided both groups with opportunities to experience the familiar in new ways through the other's eyes. Although this project showed the practicality of simplifying knowledge and abstracting it from a specific group of people, such an approach is really not that helpful if collaboration is being sought and decisions that affect people's lives need to be made.

Some of the articles achieve the book's goal of advocating for, preparing, and providing an integrated vision for dealing with Arctic and global climate change, but the effect is more compelling if one reads the book as a whole. It provides the reader with both knowledge and experience of diversity, making a strong case for development of (cross-cultural) learning opportunities, international and interdisciplinary research programs and facilities, and conversion from rectangular to round negotiating tables. The book lends itself for use in high schools, and in higher and adult education. The texts are well written and accessible. The science and the social, political, and cultural arguments are solid and updated. Reading about climate change in the Arctic from various perspectives not only helps to interconnect the scientific with the human dimension, but also gives a face to the otherwise very abstract concept of climate change and brings it, therefore, closer to home. For social scientists working in the Arctic, it provides a useful guide to the environmentally driven and rapidly changing aspects of Arctic life.

\author{
A. Nicole Stuckenberger \\ Institute of Arctic Studies \\ John Sloan Dickey Center for International Understanding \\ Dartmouth College \\ Hanover, NH 03755, USA \\ astuckenberger@lstc.edu
}

